\title{
Heat stress diminishes gonadotropin receptor expression and enhances susceptibility to apoptosis of rat granulosa cells
}

\author{
Takashi Shimizu ${ }^{1}$, Izumi Ohshima ${ }^{1}$, Manabu Ozawa ${ }^{1}$, Satoko Takahashi ${ }^{1}$, Atsushi Tajima ${ }^{1}$, \\ Masayuki Shiota ${ }^{2}$, Hitoshi Miyazaki ${ }^{2}$ and Yukio Kanai ${ }^{1}$ \\ ${ }^{1}$ Institute of Agriculture and Forestry and ${ }^{2}$ Gene Research Center, University of Tsukuba, Tsukuba, \\ Ibaraki 305-8572, Japan
}

Correspondence should be addressed to Y Kanai; Email: kanaiy@sakura.cc.tsukuba.ac.jp

T Shimizu is now at Department of Agriculture and Life Science, Obihiro University of Agriculture and Veterinary Medicine, Inada-machi, Obihiro, Hokkaido 0808555, Japan

\begin{abstract}
Heat stress inhibits ovarian follicular development in mammalian species. We hypothesized that heat stress inhibits the function of follicular granulosa cells and suppresses follicular development. To test this, immature female rats were injected with pregnant mare serum gonadotropin (PMSG) at $48 \mathrm{~h}$ after the start of temperature treatment (control: $25{ }^{\circ} \mathrm{C}, 50 \% \mathrm{RH}$; heat stress: $35^{\circ} \mathrm{C}, 70 \%$ Relative Humidity). The ovaries and granulosa cells of follicles at different developmental stages were analyzed for gonadotropin receptor levels and aromatase activity; estradiol levels were measured in follicular fluid. Before injection, heat stress diminished only the amount of FSH receptor on granulosa cells of antral follicles. During PMSG-stimulated follicular development, heat stress strongly inhibited gonadotropin receptor levels and aromatase activity in granulosa cells, and estradiol levels in the follicular fluid of early antral, antral and preovulatory follicles. To examine apoptosis and mRNA levels of $b c l-2$ and bax in granulosa cells, follicles harvested $48 \mathrm{~h}$ after PMSG injection were cultured in serum-free conditions. Heat-stressed granulosa cells showed a time-dependent increase in apoptosis. The $b c l-2 \mathrm{mRNA}$ levels were similar in control and heat-stressed granulosa cells; bax mRNA levels were increased in heat-stressed granulosa cells. According to these results, heat stress inhibits expression of gonadotropin receptors in granulosa cells and attenuates estrogenic activity of growing follicles, granulosa cells of heat-stressed follicles are susceptible to apoptosis, and the bcl2/bax system is not associated with heat-stress-induced apoptosis of granulosa cells. Our study suggests that decreased numbers and function of granulosa cells may cause ovarian dysfunction in domestic animals in summer.

Reproduction (2005) 129 463-472
\end{abstract}

\section{Introduction}

Heat stress inhibits ovarian follicular development in mammals such as domestic animals and rodents, and this can contribute to diminished reproductive efficiency during summer. In domestic animals, heat stress has been found to reduce the size of the dominant follicle by day 8 (Badinga et al. 1993) and between days 11 and 21 of the estrus cycle (Wilson et al. 1998a,b). In rodents, heat stress promoted follicular atresia and resulted in a decreased number of oocytes ovulated in immature female rats primed with pregnant mare serum gonadotropin (PMSG) (Shimizu et al. 2000).

During follicular development, the dominant follicles acquire high estrogenic activity compared with other follicles. Follicular estrogenic activity depends on the capacity for estrogen production of the granulosa cells (Fortune 1994). Estrogen production is stimulated by the binding of follicle-stimulating hormone (FSH) to its receptors on the granulosa cell membrane, activating the aromatase enzyme that converts testosterone to estradiol (Dorrington et al. 1975, Erickson and Hsueh 1978). In turn, the synthesized estradiol contributes to the maintenance and expression of receptors for luteinizing hormone (LH) and FSH (LH-R and FSH-R respectively) on granulosa cells (Hsueh et al. 1994, Bodensteiner et al. 1995). Heat stress was found to suppress aromatase activity in granulosa cells and decrease the estradiol concentrations in the follicular fluid and plasma of dairy cows (Badinga et al. 1993). In addition, in both lactating cows and heifers, heat stress decreased serum estradiol concentration between days 11 and 21 of the estrus cycle (Wilson et al. $1998 a, b)$. Seasonal and acute heat stresses were found to affect steroid production in the dominant follicles of cows (Wolfenson et al. 1997). These findings demonstrated that heat stress affects the viability of granulosa cells and the follicular estrogenic activity. However, the mechanism by 
which heat stress suppresses estrogen production has not been investigated.

Follicular cells in atretic follicles are normally eliminated by apoptosis (Tilly 1993, Palumbo and Yeh 1994), as can be observed in granulosa cells during follicular development (Tilly 1996). Apoptosis of granulosa cells is provoked by the lack of survival factors such as FSH and estradiol (Billing et al. 1993, Chun et al. 1996). Although it has been shown that heat stress suppresses estradiol production in the dominant follicle (Badinga et al. 1993), it is unknown whether this suppression results in granulosa cell apoptosis. Recently, the expression of genes encoding apoptosis-regulating proteins in the follicle has been reported. Two members of the $b c l-2$ family, $b c l-2$ and bax, have been shown to regulate apoptosis in the ovary (Tilly et al. 1995, Adams and Cory 1998, Goodman et al. 1998). In the rat ovary, Bax appears to antagonize the apoptosis-suppressive effects of $\mathrm{BCl}-2$, and the fate of the cell appears to be decided by the balance between these two regulatory proteins (Tilly et al. 1995). In addition, previous study has reported that the ability of gonadotropins to prevent apoptosis and atresia in ovarian follicles may be linked to a shift in the ratio of bcl-2 to bax gene expression (Tilly et al. 1995).

The objective of the present study was to determine whether heat stress affects the estrogen production system and whether granulosa cells in follicles isolated from heat-stressed immature female rats have an increased susceptibility to apoptosis. In addition, we investigated possible cellular mechanisms for the apoptosis induction of granulosa cells from heat-stressed animals.

\section{Materials and Methods}

\section{Animal and heat stress treatment}

Three-week-old immature Wistar female rats (Charles River Inc., Tokyo Japan) were used. The animals were divided into two groups (control and heat stress), kept in separate cages, and housed in a climate-controlled chamber at $25^{\circ} \mathrm{C}$ and $50 \%$ relative humidity, with a 12:12 h light:dark cycle (lights on at $0600 \mathrm{~h}$ ). Each animal received a subcutaneous injection of $20 \mathrm{IU}$ of PMSG (Teikoku Hormone Co., Tokyo Japan) at $48 \mathrm{~h}$ after the start of the temperature treatment. The heat stress group was exposed to $35^{\circ} \mathrm{C}$ and $70 \%$ relative humidity conditions from $48 \mathrm{~h}$ before PMSG injection to $48 \mathrm{~h}$ after injection (for 4 days). The animals were allowed rat chow (MF pellet, Charles River Inc.) and water ad libitum.

\section{Follicle isolation and extraction of granulosa cells}

The ovaries were removed from the rats either before or $48 \mathrm{~h}$ after injection of PMSG. The isolation and size classification of the follicles from the ovaries were performed by the methods of Roy and Greenwald (1985). The ovaries were separated by fine forceps and incubated in Medium
199 with $25 \mathrm{mM}$ Hepes containing type I collagenase, DNase (bovine pancreas type III) and protease, in addition to $1 \%$ bovine serum albumin (BSA) (all purchased from Sigma) for $40 \mathrm{~min}$ at $37^{\circ} \mathrm{C}$. Subsequently, Medium 199 containing $1 \%$ BSA was added, and the mixture was centrifuged at 600 r.p.m. for 4 min. The supernatant was discarded, and the pellet was resuspended in fresh Medium 199. The dispersed follicles were then separated by successive passage through nylon mesh of appropriate pore sizes to yield follicles with diameters of $<185 \mu \mathrm{m}$ (preantral follicles), 186-350 $\mu \mathrm{m}$ (early antral follicles), $351-500 \mu \mathrm{m}$ (antral follicles) and $>500 \mu \mathrm{m}$ (preovulatory follicles). The granulosa cells and follicular fluid were separated from the collected follicles of different developmental stages. The number of each type of granulosa cells was counted on a hemocytometer and adjusted to $2.5 \times 10^{5}$ cells $/ 100 \mu \mathrm{l}$.

\section{Receptor binding assays}

Highly purified rat FSH (NIDDK-rFSH-I-8) and $\mathrm{LH}$ (NIDDK-rLH-I-9) were radioiodinated by the lactoperoxidase method. Single-point saturation analysis was used to determine the numbers of FSH and $\mathrm{LH}$ receptors in granulosa cells, as described previously (Kawate et al. 1990).

\section{${ }^{125}$ I-rFSH binding assay}

Aliquots $(100 \mu \mathrm{l})$ of granulosa cells were incubated for $3 \mathrm{~h}$ at $37^{\circ} \mathrm{C}$ with a single dose of ${ }^{125} \mathrm{I}$-labeled rat FSH ( $\mathrm{rFSH}$, $2.5 \mu \mathrm{g} ; 3 \times 10^{5}$ c.p.m. $/ 100 \mu \mathrm{l}$ ) in $100 \mu \mathrm{l} \mathrm{FSH}$ assay buffer consisting of $0.01 \mathrm{M} \mathrm{PBS}(\mathrm{pH} 7.4), 0.1 \%$ BSA and $5 \mathrm{mM}$ magnesium chloride. The cells were washed twice with $2 \mathrm{ml} \mathrm{FSH}$ assay buffer, and the bound ${ }^{125}$ I activities in the granulosa cell pellets were counted on a gamma counter. Nonspecific binding (NSB) was assessed in the presence of excess FSH (purified from porcine pituitary extract, $500 \mu \mathrm{g} / \mathrm{tube})$.

\section{${ }^{125}$ I-rLH binding assay}

Aliquots $(100 \mu \mathrm{l})$ of granulosa cells were incubated for $18 \mathrm{~h}$ at $37^{\circ} \mathrm{C}$ with a single dose of ${ }^{125} \mathrm{I}$-labeled rat $\mathrm{LH}$ (rLH, $2.5 \mu \mathrm{g}: 2 \times 10^{5}$ c.p.m. $\left./ 100 \mu \mathrm{l}\right)$ in $100 \mu \mathrm{l}$ of $\mathrm{LH}$ assay buffer $(0.01 \mathrm{M}$ PBS containing $0.1 \% \mathrm{BSA}, \mathrm{pH} 7.4)$. After incubation, the cells were washed twice with $2 \mathrm{ml} \mathrm{LH}$ assay buffer and counted on a gamma counter. NSB was assessed in the presence of excess chorionic hormone (hCG) (100 IU/tube).

The NSB was less than $1 \%$ of the added radioactivity in both the FSH and $\mathrm{LH}$ receptor binding assays. The amount of specific binding to $\mathrm{rFSH}$ and $\mathrm{rLH}$ was expressed as $\mathrm{pg} / 2.5 \times 10^{5}$ cells.

\section{Aromatase activity assay}

The aromatase activity assay was performed as previously described (Thatcher et al. 1991). Aliquots $(100 \mu \mathrm{l})$ of 
granulosa cells were incubated with $\left[{ }^{3} \mathrm{H}\right]$ testosterone $(0.5 \mu \mathrm{Ci})$ in $4 \mathrm{ml}$ Medium 199 for $4 \mathrm{~h}$ at $37^{\circ} \mathrm{C}$ in a $95 \%$ $\mathrm{O}_{2} / 5 \% \mathrm{CO}_{2}$, humidified environment. The aromatase activity was measured as the stereospecific cleavage of ${ }^{3} \mathrm{H}$ from the radiolabeled testosterone and the consequent release of ${ }^{3} \mathrm{H}_{2} \mathrm{O}$ into the medium; activity was expressed as d.p.m. $/ 2.5 \times 10^{5}$ cells.

\section{Estradiol concentration in the follicular fluid}

The estradiol content in the follicular fluid was measured by radioimmunoassay, as previously described (Kanai and Shimizu 1986). Briefly, the estradiol in the follicular fluid $(200 \mu \mathrm{l})$ was extracted with $2.5 \mathrm{ml}$ benzene. The minimum detection level of the assay was $1.0 \mathrm{pg} / \mathrm{ml}$. The intra-assay coefficient of variation was $8.2 \%$. The estradiol content in the follicular fluid was expressed as $\mathrm{pg} / \mathrm{ml}$ per follicle.

\section{Culture of follicles}

Follicles at different developmental stages were dissected from the ovaries collected at $48 \mathrm{~h}$ after the PMSG injections in both groups. Culture of the follicles was performed as previously described (Chun et al. 1994). The follicles from three animals were pooled and cultured in glass tubes containing $1 \mathrm{ml}$ Eagle's minimal essential medium (Gibco BRL, Gaithersburg, MD, USA) supplemented with penicillin, streptomycin, L-glutamine and $0.1 \%$ BSA. Thirty early antral, 15 antral and 5 preovulatory follicles were cultured in each glass tube. The cultures were maintained for $6,12,18$ and $24 \mathrm{~h}$ at $37^{\circ} \mathrm{C}$ and $95 \% \mathrm{O}_{2} / 5 \%$ $\mathrm{CO}_{2}$. At each time point, the granulosa cells were isolated from the follicle, and a portion of the cells underwent Hoechst staining; the remainder were snap-frozen and stored at $-80^{\circ} \mathrm{C}$ until DNA isolation.

\section{Hoechst staining, DNA isolation and fragmentation analysis}

Granulosa cells from follicles at different developmental stages were fixed in $1 \%$ glutaraldehyde overnight and stained with $1 \mathrm{mM}$ Hoechst 33342 (Sigma) for $1 \mathrm{~min}$. The samples were examined by fluorescence microscopy with an ultraviolet light filter. Calculation of the percentage of apoptotic granulosa cells, including shrunken cells, was based on a count of 200 cells.

Cellular DNA was extracted from the granulosa cells of preovulatory follicles and analyzed as previously described (Chun et al. 1994). Aliquots containing 500 ng DNA were labeled at the $3^{\prime}$-ends with $\left[\alpha-{ }^{32} \mathrm{P}\right]$ dideoxy-ATP $(25 \mu \mathrm{Ci}$, $6000 \mathrm{Ci} / \mathrm{mmol}$; Amersham Pharmacia Biotech, UK), using terminal transferase (Nippon Gene, Tokyo, Japan). Equal amounts of the labeled DNA samples ( $250 \mathrm{ng} / \mathrm{lane}$ ) were fractionated by electrophoresis through $2 \%$ agarose gels. The gels were dried in a gel dryer and exposed on an imaging plate (Fuji Film Co. Tokyo, Japan). After exposure, the portion of each lane corresponding to DNA smaller than $15 \mathrm{~kb}$ was counted with a BAS-5000 computer-based imaging system (Fuji Film) for quantitation of the degree of apoptotic DNA fragmentation. All data are expressed as the percentage of the control value at $0 \mathrm{~h}$ of culture.

\section{Preparation of deletion-mutated cDNA competitors for competitive reverse transcription-polymerase chain reaction (RT-PCR) analysis}

Partial fragments of the sequences encoding Bcl-2, Bax, and $\beta$-actin were obtained by RT-PCR with the following primers: $b c l-2$ sense, 5'-CTG GGG ATG ACT TCT CTC G$3^{\prime}$, and antisense, 5'-GGA GAA ATC AAA CAG AGG TC3'; bax sense, 5'-AGA CAC CTG AGC TGA CCT TG-3', and antisense, 5'-GTC CCG AAG TAG GAG AGG AG-3'; $\beta$-actin sense, 5'-CAA CCT CCT TGC AGC TCC TC-3', and antisense, 5'-GAC CAG AGG CAT ACA GGG AC-3'. These fragments were blunt-ended, phosphorylated at their $5^{\prime}$-ends and inserted into the EcoRV site of pBluescript KS (+) (Stratagene, La Jolla, CA, USA). The resultant $b c l-2$ plasmid was digested with BstXI and Hincll, and the bax plasmid was digested with AvaL to create the deletion mutations. The single-stranded ends were blunted with T4-DNA polymerase, and the plasmids were self-ligated. The mutated competitors were amplified by PCR, using the primers described above, and resolved by PAGE. The amplified cDNA fragments were recovered, quantified and used as internal standards for quantitative competitive RT-PCR.

\section{Competitive RT-PCR}

Total RNAs $(3.0 \mu \mathrm{g})$ extracted from granulosa cells were reverse-transcribed with random primers, and the resultant cDNA mixtures were amplified by PCR, using the same primers described above in the presence of various amounts of the mutant competitor cDNAs and a trace amount of $\left[\alpha-{ }^{32} \mathrm{P}\right] \mathrm{dCTP}$ to permit quantification of the PCR products. The denaturation, annealing and polymerization cycles were performed as $58{ }^{\circ} \mathrm{C}$ for $1 \mathrm{~min}, 65^{\circ} \mathrm{C}$ for $1 \mathrm{~min}$ and $58^{\circ} \mathrm{C}$ for $1 \mathrm{~min}$ respectively. The cycles were repeated 32,30 and 28 times for amplification of the $b c l-2$, bax and $\beta$-actin sequences, respectively. The final incubation was continued at $72{ }^{\circ} \mathrm{C}$ for $8.5 \mathrm{~min}$ to complete the polymerization. Native bcl-2, bax, and $\beta$-actin cDNAs produced 334, 378, and $490 \mathrm{bp}$ fragments, respectively, whereas the cDNA for the deletion mutant competitors of $b c l-2$, bax, and $\beta$-actin generated 243, 263 and $377 \mathrm{bp}$ fragments (target PCR product) respectively. The PCR products were fractionated by electrophoresis on $5 \%$ polyacrylamide gels. The gels were dried and analyzed by a BAS 5000 computer-based imaging system. The level of $\beta$-actin mRNA in rat follicle cells has been found to be independent of the follicle status and size (Tilly et al. $1992 b)$, and $\beta$-actin expression is not affected by growth factors or gonadotropins (Hooley et al. 1979, Weiner and Dias 1993). Therefore, the quantitation of the $b c l-2$ and bax PCR products was normalized to that of the $\beta$-actin PCR product. 


\section{Data analysis}

All results were expressed as means \pm standard error of the mean (S.E.M.). The significance of the differences in the amounts of FSH-R and LH-R, the aromatase activities in granulosa cells, the concentrations of estradiol in follicular fluid and the degrees of apoptotic DNA fragmentation at different developmental stages between the control and heat stress groups were analyzed by Student's $t$-test. The statistical differences in the percentages of apoptotic granulosa cells were analyzed by the arcsin test.

\section{Results}

Effects of heat stress on the number of granulosa cells, the aromatase activity and the estradiol concentration in follicular fluid before and after PMSG treatment

The number of granulosa cells obtained from follicles at different developmental stages increased as the follicle grew and did not differ significantly between the control and the heat stress groups before or after PMSG treatment (Fig. 1A and B). The aromatase activity in granulosa cells remained unchanged in preantral, early antral and antral follicles before PMSG treatment (Fig. 2A). By contrast, after PMSG treatment, the aromatase activity increased in granulosa cells from early antral, antral and preovulatory follicles in both the heat stress and control groups; however, the aromatase activity was lower in the heat stress group than that in the control group for all developmental stages (Fig. 2B). The estradiol concentration in the follicular fluid was low (baseline levels) in preantral, early antral and antral follicles before PMSG treatment (Fig. 3A). After PMSG treatment, the follicular estradiol concentration increased, particularly in antral and preovulatory follicles, in both groups, but the levels were lower in the heat stress group than those in the control group (Fig. 3B).

\section{Effects of heat stress on FSH-R and LH-R in granulosa cells before and after PMSG treatment}

The amount of FSH-R in granulosa cells before PMSG treatment increased as the follicles grew; a significantly lower amount of FSH-R in the heat stress group than in the control group was found only in the granulosa cells from antral follicles (Fig. 4A). After PMSG treatment, the amount of $\mathrm{FSH}-\mathrm{R}$ in granulosa cells increased markedly in follicles at all developmental stages in both groups. However, compared with the controls, the heat stress group had significantly lower amounts of FSH-R in cells from early antral, antral and preovulatory follicles (Fig. $4 \mathrm{~B})$. The amount of LH-R in the granulosa cells remained unchanged in preantral, early antral and antral follicles in both groups before PMSG treatment (Fig. 5A). After PMSG treatment, the amount of LH-R increased markedly in the antral and preovulatory, but not early antral,
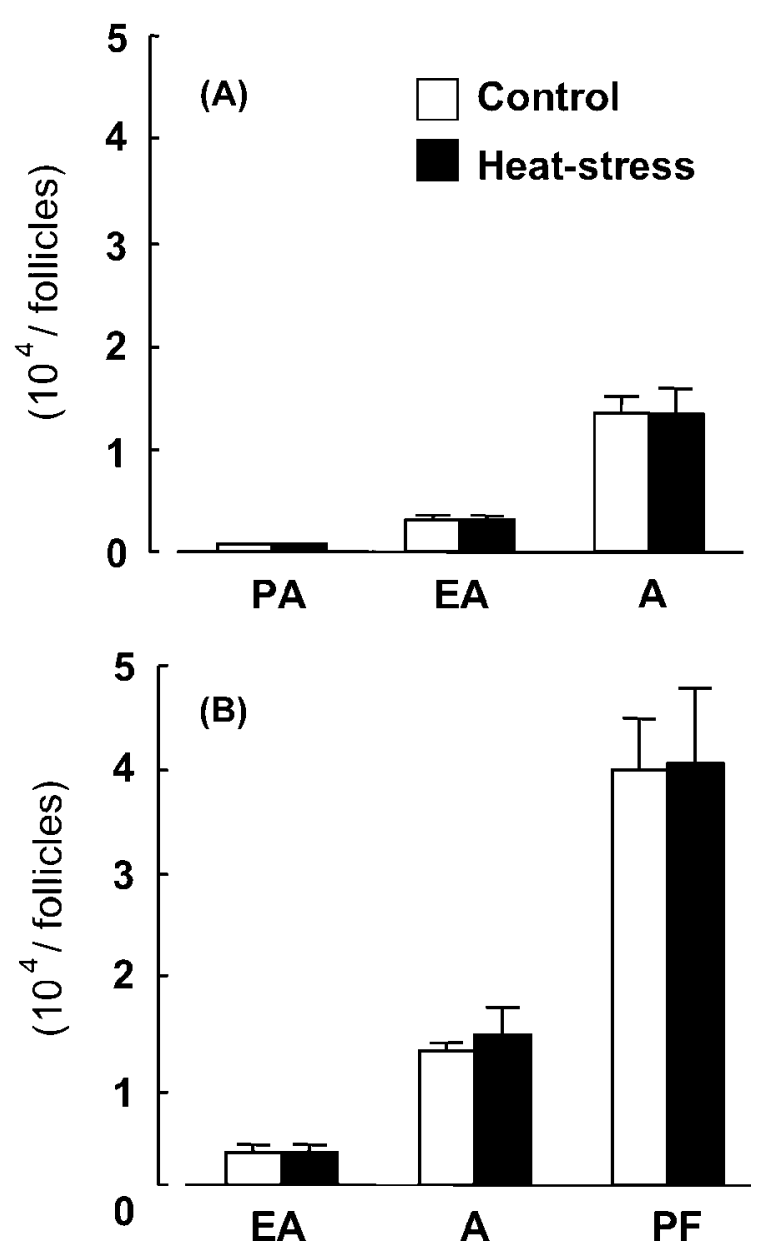

Figure 1 Effect of heat stress on the number of granulosa cells in follicles at different developmental stages harvested from immature female rat ovaries before (A) or after (B) PMSG treatment. Heat stress did not affect the number of granulosa cells before or after PMSG treatment. The data are presented as means \pm S.E.M. of four independent experiments. PA, preantral; EA, early antral; A, antral; PF, preovulatory. The open and solid bars indicate the control and heat-stress groups respectively.

follicles of the control group; however, in the heat stress group, the levels of LH-R were significantly lower in the antral and preovulatory follicles than those in the controls (Fig. 5B).

\section{Susceptibility to apoptosis of granulosa cells from heat-stressed follicles}

Follicles at different developmental stages were obtained from ovaries at $48 \mathrm{~h}$ after the injection of PMSG and were cultured for $0,6,12,18$ and $24 \mathrm{~h}$ under serum-free conditions. Hoechst 33342 staining was used to examine the nuclear morphology of the granulosa cells from the follicles (Fig. 6A). Cells with small pyknotic nuclei and highly condensed chromatin were considered apoptotic. The percentage of apoptotic granulosa cells from early antral, antral and preovulatory follicles at $0 \mathrm{~h}$ of culture 

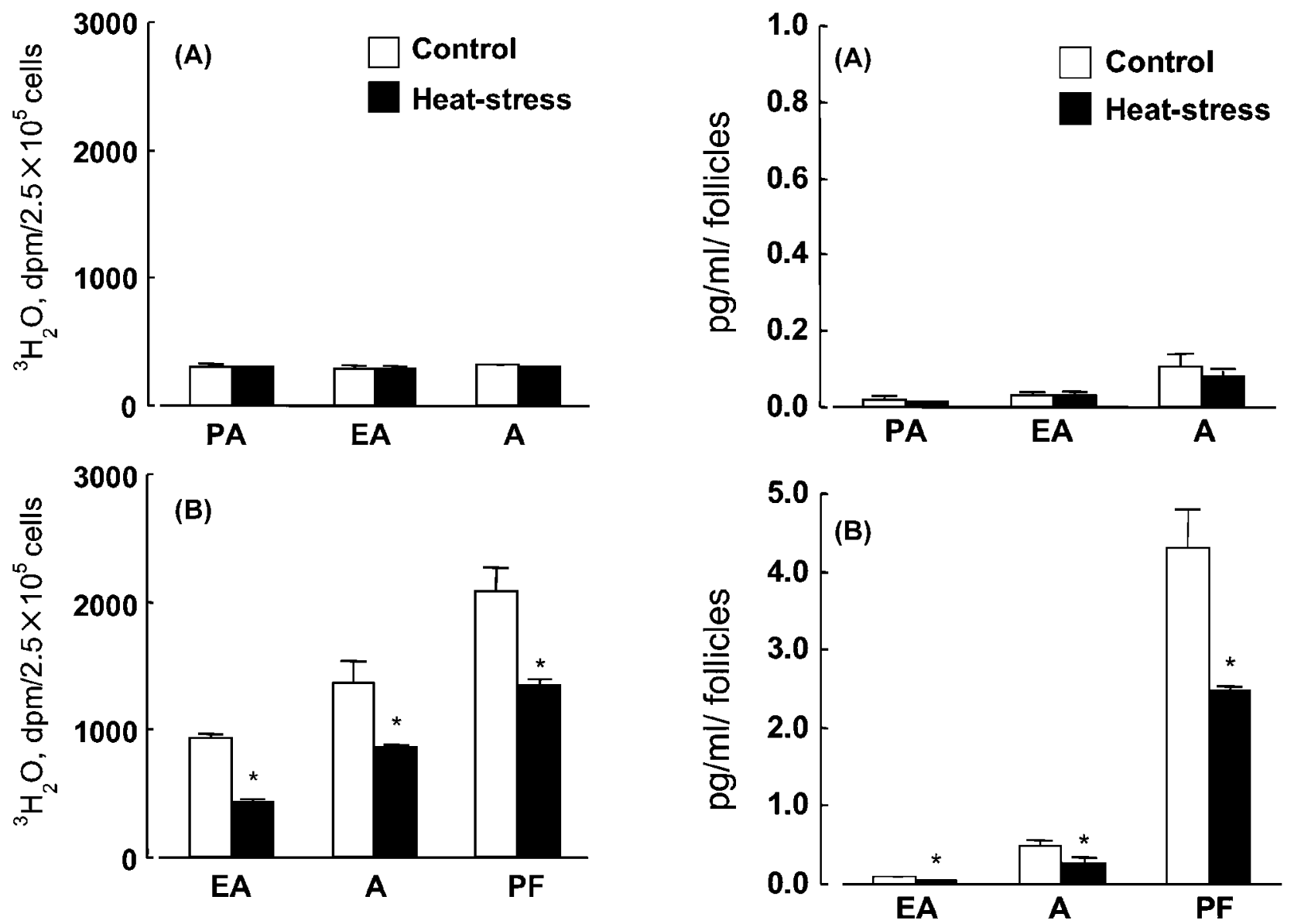

Figure 2 Effect of heat stress on aromatase activity in granulosa cells of follicles at different developmental stages harvested from immature female rat ovaries before (A) or after (B) PMSG treatment. (A) Heat stress did not suppress aromatase activity in granulosa cells before PMSG treatment. (B) Heat stress suppressed aromatase activity in granulosa cells after PMSG treatment. The data are presented as means \pm S.E.M. of four independent experiments. Asterisks denote significantly different values $(P<0.05)$. PA, preantral; EA, early antral; $\mathrm{A}$, antral; $\mathrm{PF}$, preovulatory. The open and solid bars indicate the control and heat-stress groups respectively.

did not differ significantly between the heat stress and control groups (Fig. 6A-C). The percentage of apoptotic cells increased markedly in the control group by 18 and $24 \mathrm{~h}$ in serum-free culture. In contrast, the percentage of apoptotic cells in the heat stress group increased in a time-dependent manner in follicles at each developmental stage.

The analysis of DNA fragmentation in granulosa cells from early antral, antral and preovulatory follicles cultured in serum-free conditions exhibited the typical apoptotic DNA degradation pattern of internucleosomal fragments of $185 \mathrm{bp}$ multiples (Fig. 7A-C). The quantifications of the low-molecular-weight DNA content of early antral, antral and preovulatory follicles were consistent with the Hoechst stain observations and demonstrated a significant increase in apoptosis at 12 and $24 \mathrm{~h}$ of culture in the 

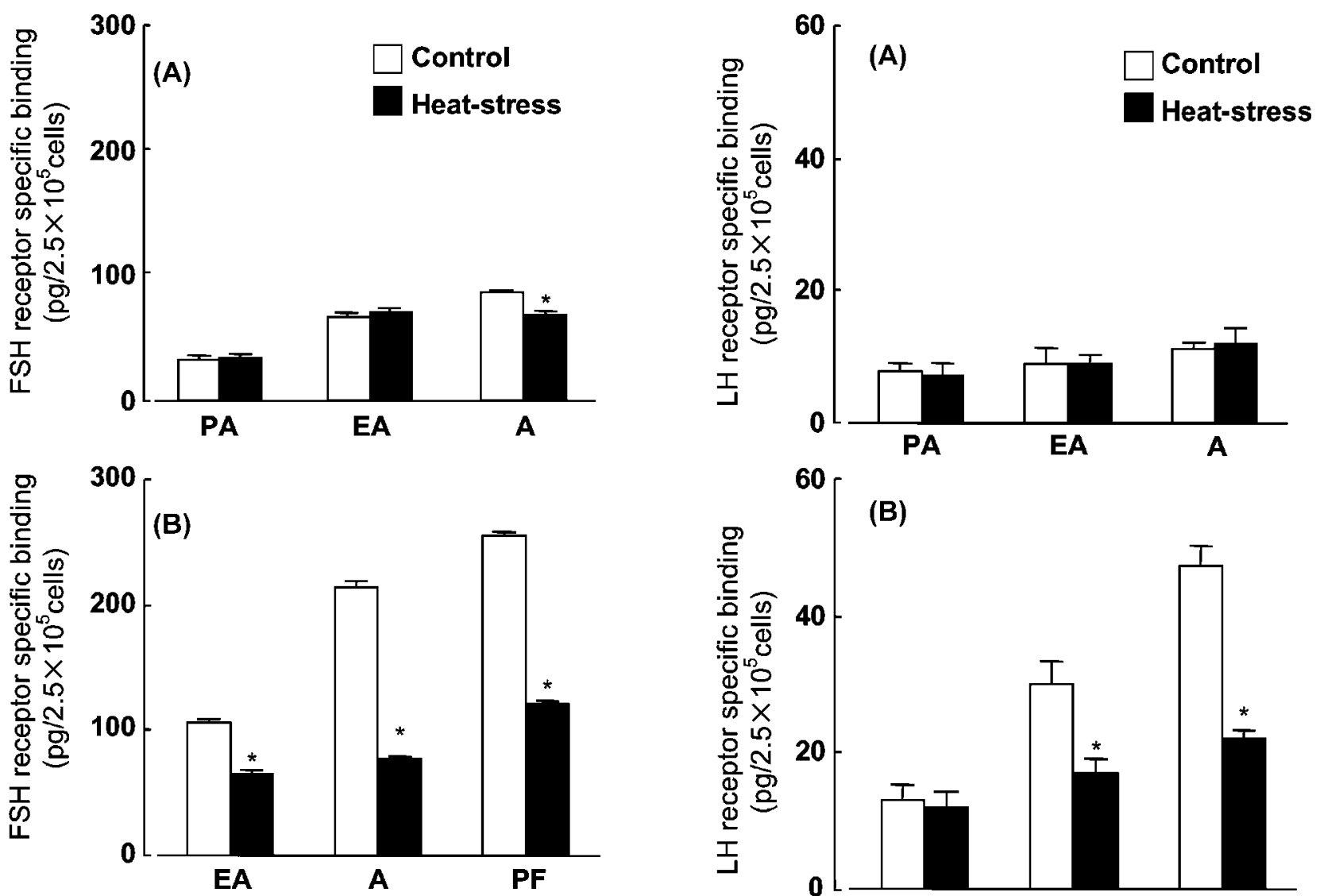

Figure 4 Effect of heat stress on FSH-R levels on granulosa cells of follicles at different developmental stages harvested from immature female rat ovaries before (A) or after (B) PMSG treatment. (A) Before PMSG treatment, heat stress suppressed FSH-R levels only on the granulosa cells of antral follicles. (B) After PMSG treatment, heat stress suppressed FSH-R levels on granulosa cells. The data are presented as means \pm S.E.M. of four independent experiments. Asterisks denote significantly different values $(P<0.05)$. PA, preantral; EA, early antral; $A$, antral; $P F$, preovulatory. The open and solid bars indicate the control and heat-stress groups respectively.

\section{Discussion}

The results of the present study provide evidence that heat stress inhibits $\mathrm{FSH}-\mathrm{R}$ expression in granulosa cells and results in low estrogenic activity in the follicles, that decreased FSH-R expression is associated with enhanced susceptibility to apoptosis in granulosa cells, and that the bcl-2/bax system may be not associated with heat-stressinduced apoptosis in granulosa cells.

In the present study, heat stress suppressed the aromatase activity in granulosa cells and resulted in a low capacity for estradiol production in the follicles. Several stress-associated factors, including corticoid and prolactin, affect aromatase activity. Prolactin levels were increased when animals were acutely exposed to high environmental temperatures (Hooley et al. 1979), thus inhibiting aromatase activity in rat granulosa cells (TsaiMorris et al. 1983, Krasnow et al. 1990). In addition,

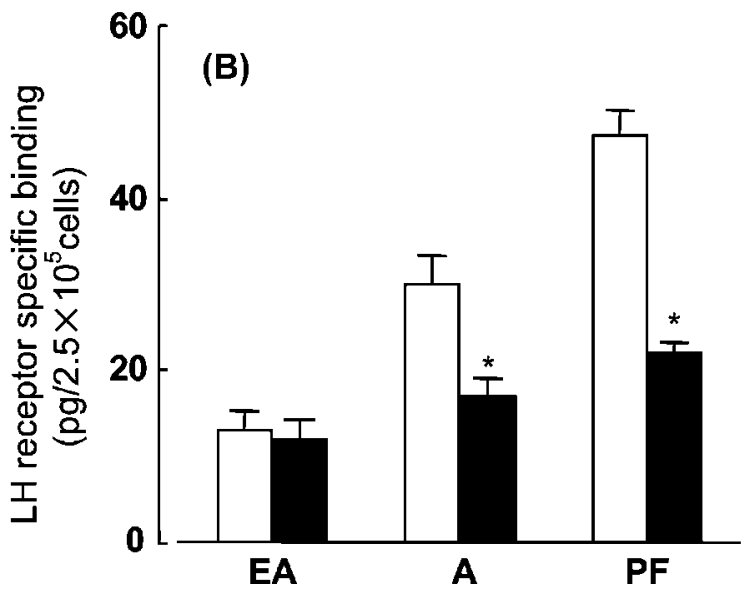

Figure 5 Effect of heat stress on LH-R levels on granulosa cells of follicles at different developmental stages harvested from immature female rat ovaries before (A) or after (B) PMSG treatment. (A) Before PMSG treatment, heat stress did not suppress LH-R levels in granulosa cells. (B) After PMSG treatment, heat stress suppressed LH-R levels in granulosa cells of antral and preovulatory follicles. The data are presented as means \pm S.E.M. of four independent experiments. Asterisks denote significantly different values $(P<0.05)$. PA, preantral; EA, early antral; A, antral; PF, preovulatory. The open and solid bars indicate the control and heat-stress groups respectively.

glucocorticoids selectively inhibited FSH-induced aromatase activity in rat granulosa cells (Hsueh and Erickson 1978). Furthermore, in the present study, the inhibition of aromatase activity by heat stress may have resulted from increases in prolactin and glucocorticoid levels. The steroidogenic CYP19 gene encoding the aromatase cytochrome P450 enzyme is induced in granulosa cells from rat preovulatory follicles in vivo (Hickey et al. 1988) and in vitro (Hickey et al. 1990, Krasnow et al. 1990). Aromatase mRNA can be superinduced in cells differentiated by exposure to $\mathrm{LH}$ and cycloheximide, suggesting that the steady-state levels of mRNA involve not only transcriptional control but also mRNA stability (Fitzpatrick and Richards 1991). The rat aromatase promoter has a TATA motif and a single transcriptional initiation site (Fitzpatrick and Richards 1991). Thus, heat stress may affect transcriptional regulation and control of 

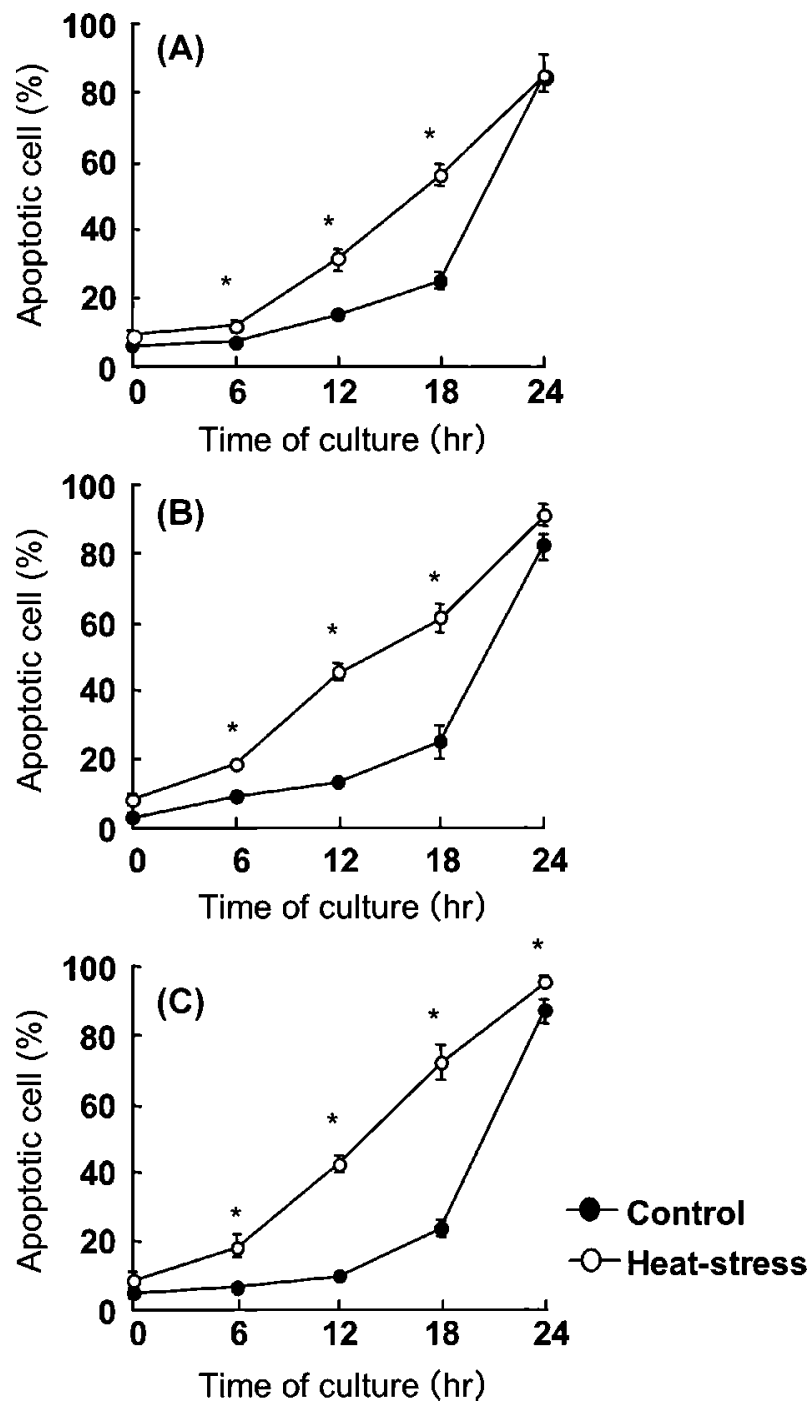

Figure 6 Detection of apoptosis in granulosa cells of cultured early antral (A), antral (B) and preovulatory (C) follicles with Hoechst 33342 staining. Follicles at different developmental stages were cultured for $0,6,12,18$ and $24 \mathrm{~h}$ in serum-free medium. The data are presented as means \pm S.E.M. of four independent experiments. Asterisks denote significantly different values $(P<0.05)$ compared with the controls. The solid and open circles indicate the control and heat-stress groups respectively.

the initiation site, as well as stability of aromatase mRNA, in granulosa cells.

Our findings indicate that heat stress suppresses LH-R expression in granulosa cells of antral and preovulatory follicles after PMSG treatment. As LH-R expression in granulosa cells is induced by estradiol, heat-stress-induced decreases in the estradiol concentration in the follicular fluid may result in the inhibition of LH-R expression in the granulosa cells. Interestingly, in the present study, heat stress induced a decrease in the estradiol concentration in the follicular fluid of early antral follicles after PMSG treatment, but did not suppress LH-R expression in the granulosa cells. LH/ hCG receptors are expressed predominantly on the thecal cells of small antral follicles, whereas LH/hCG receptors are expressed on both granulosa and thecal cells in large antral follicles (Camp et al. 1991, Peng et al. 1991, Teerds and Dorrington 1995). Our findings suggest that heat stress may inhibit LH-R expression in thecal cells, rather than in granulosa cells, of follicles at the early antral stage.

FSH receptors are confined to the granulosa cells of healthy, developing follicles (Camp et al. 1991). Estradiol contributes to the maintenance and expression of both LH-R and FSH-R in granulosa cells (Hsueh et al. 1994, Bodensteiner et al. 1995). In the present study, we found that, although the concentration of estradiol in the follicular fluid was already at baseline levels before PMSG treatment, heat stress nonetheless inhibited FSH-R expression in the granulosa cells of antral follicles. This result suggests that FSH-R expression in the granulosa cells is also regulated by estradiol-independent mechanisms.

The administration of PMSG results in a marked increase of FSH-R mRNA expression and FSH-binding sites (Nakamura et al. 1991, LaPolt et al. 1992). FSH-R expression in granulosa cells is also induced by locally produced intraovarian growth factors, such as transforming growth factor-beta (TGF- $\beta$ ) (Tilly et al. 1992a, GitayGoren et al. 1993, Dunkel et al. 1994) and insulin-like growth factor-I (IGF-I) (Zhou et al. 1997). Our study indicates that heat stress suppresses FSH-R expression in granulosa cells of follicles at the early antral, antral and preovulatory stages after PMSG treatment. This finding suggests that the increase in atresia caused by heat stress (Shimizu et al. 2000) may be induced by the inhibition of FSH-R expression in granulosa cells.

The lack of follicular survival factors such as FSH and estradiol leads to granulosa cell apoptosis characterized by DNA fragmentation and follicular somatic cell condensation. In the present study, granulosa cells of follicles harvested from heat-stressed, immature, female rats after PMSG treatment rapidly underwent DNA fragmentation when cultured under serum-free conditions, suggesting that heat-stressed follicles are highly susceptible to apoptosis. Thus, we hypothesized that apoptosis-related genes might already be expressed at $0 \mathrm{~h}$ of culture time in the granulosa cells of heat-stressed follicles.

One key group of intracellular factors regulating apoptosis is the Bcl-2 family of proteins (Adams and Cory 1998). The members of this family can be subdivided into antiapoptotic proteins (such as $\mathrm{BCl}-2$ and $\mathrm{BCl}-\mathrm{xL}$ ) and proapoptotic proteins (such as Bax and BAD). It has been proposed that anti- and proapoptotic proteins regulate cell death by binding to each other and forming heterodimers (Oltvai et al. 1993, Yang et al. 1995). According to this model, a delicate balance between anti- and proapoptotic $\mathrm{Bcl}-2$ family members exists in each cell, and the relative concentrations of these two groups of proteins determine whether the cell survives or undergoes apoptosis. To investigate our hypothesis, we examined the expression levels of bcl-2 and bax mRNAs in granulosa cells, using 

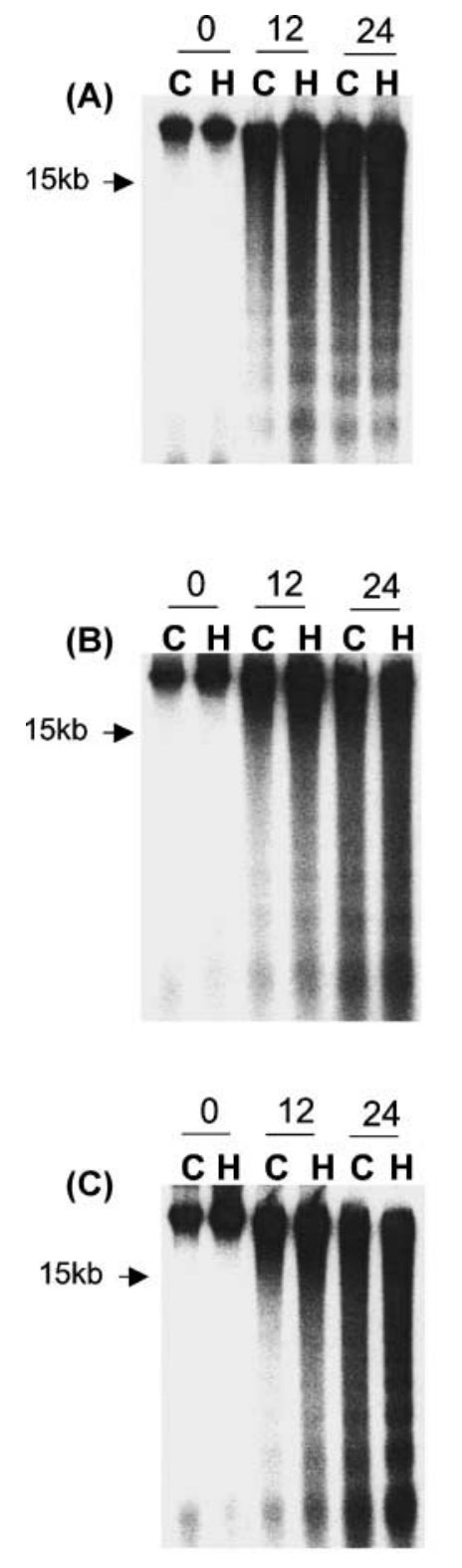
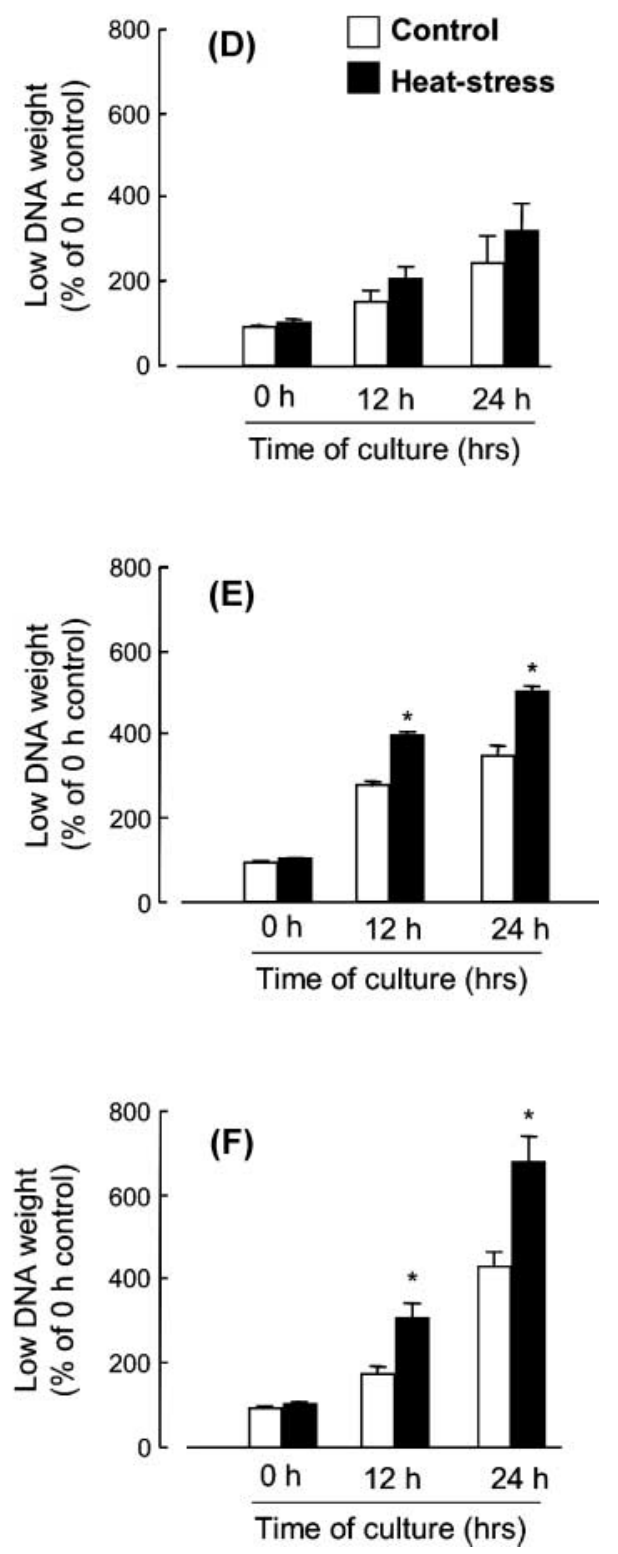

Figure 7 Detection of DNA fragmentation in granulosa cells of cultured early antral (A and D), antral (B and $\mathrm{E}$ ) and preovulatory ( $\mathrm{C}$ and $\mathrm{F}$ ) follicles. Follicles at different developmental stages were harvested from control $(\mathrm{C})$ or heat-stressed $(\mathrm{H})$ ovaries and cultured for 0,12 and $24 \mathrm{~h}$ in serumfree medium. After incubation, granulosa cell DNA was extracted, labeled at the $3^{\prime}$-ends with $\left[{ }^{32} \mathrm{P}\right]$ dideoxy-ATP, and fractionated through $2 \%$ agarose gels ( $500 \mathrm{ng} / \mathrm{lane})$. DNA fragmentation was then visualized by autoradiography $(\mathrm{A}-\mathrm{C})$. The portions of each lane corresponding to DNA smaller than $15 \mathrm{~kb}$ were counted by an image-analysis system for quantitation of the degree of apoptotic DNA fragmentation. All data are expressed as the percentage of the control value at $0 \mathrm{~h}$ of culture. The data are means \pm S.E.M. of four independent experiments. Asterisks denote significantly different values $(P<0.05)$ compared with the controls. The open and solid bars indicate the control and heat-stress groups respectively. quantitative RT-PCR. Our findings indicate that the levels of bcl-2 and bax mRNA, and the ratio of bax to bcl-2 mRNA, were similar in both treatment groups at $0 \mathrm{~h}$ of culture. These observations suggest that in vivo heat stress did not affect the $b c /-2 / b a x$ apoptotic signaling pathway at the beginning of granulosa cell apoptosis in vitro. However, the expression of bax mRNA in granulosa cells of follicles from heat-stressed animals increased significantly after the 12-h culture period. This result suggests that the amount of bax present in granulosa cells that maintain a constitutive level of $b c l-2$ expression may be linked to the induction of granulosa cell apoptosis and follicular atresia mediated by heat-stress. It is known that another apoptotic signaling cascade, the Fas/Fas ligand (FasL) system, can lead to granulosa cell apoptosis (Quirk et al. 1995,
Hakuno et al. 1996, Kim et al. 1998). Thus, it is possible that heat stress stimulates the Fas/FasL cascade in the granulosa cells of growing follicles.

In conclusion, heat stress inhibits the FSH-R signaling pathway in the granulosa cells of growing follicles, causing decreased estrogen levels, which are known to produce increased follicular atresia. Thus, the regulators of FSH-R expression may be potential targets for therapeutic intervention for low summer fertility syndrome, as a substitute for therapy with estrogenic compounds.

\section{Acknowledgements}

We thank Dr Miho Hirabayashi for her helpful suggestions on RT-PCR analysis, NIDDK's National Hormone and Pituitary 

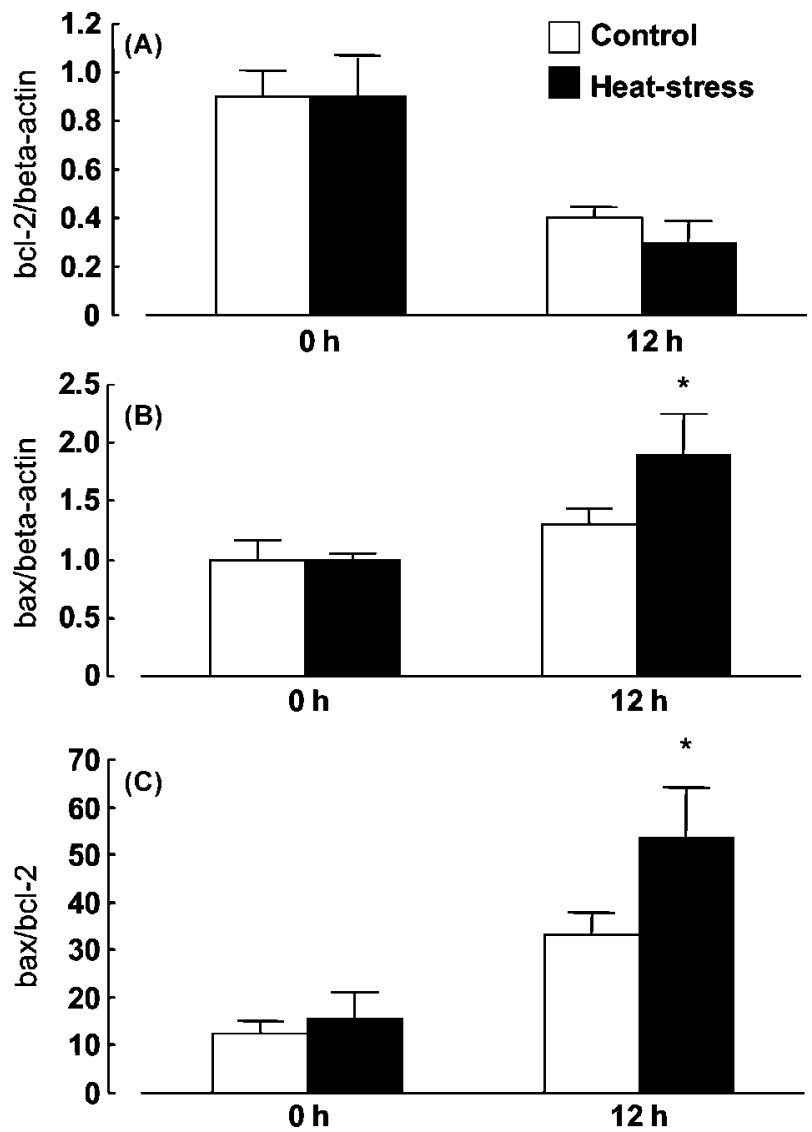

Figure 8 Effects of heat stress on expression of $b c l-2(A)$ and bax (B) mRNA and the ratio of $b c l-2 / b a x(C)$ in granulosa cells. Total RNAs $(3.0 \mu \mathrm{g})$ were reverse-transcribed with random primers, and the resultant cDNA mixtures were amplified by PCR in the presence of various amounts of deletion mutant competitor cDNAs and a trace amount of $\left[\alpha-{ }^{32} \mathrm{P}\right] \mathrm{dCTP}$ to quantify the PCR products. The PCR products were size fractionated by electrophoresis on $5 \%$ polyacrylamide gels. The data are presented as means \pm S.E.M. of four independent experiments. Asterisks denote significantly different values $(P<0.05)$ compared with the controls. The open and solid bars indicate the control and heat-stress groups respectively.

Program and Dr A F Parlow for the purified rat FSH and $\mathrm{LH}$. This work was partly supported by a Grant-in-Aid for Exploratory Research (14656098) from the Japan Society for the Promotion of Science. The authors declare that there is no conflict of interest that would affect prejudice the impartiality of this scientific work.

\section{References}

Adams JM \& Cory S 1998 The Bcl-2 protein family: arbiters of cell survival. Science 281 1322-1326.

Badinga L, Thatcher WW, Diaz T, Drost M \& Wolfenson D 1993 Effect of environmental heat stress on follicular development and steroidogenesis in lactating Holstein cows. Theriogenology 39 797-810.

Billing H, Furuta I \& Hsueh AJW 1993 Estrogens inhibit and androgens enhance ovarian granulosa cell apoptosis. Endocrinology 133 2204-2212.
Bodensteiner KJ, Wiltbanl MC, Bergfelt DR \& Ginther OJ 1995 Alternations in follicular estradiol and gonadotropin receptors during development of bovine antral follicles. Theriogenology $\mathbf{4 4}$ 499-512.

Camp TA, Rahal JO \& Mayo KE 1991 Cellular localization and hormonal regulation of follicle-stimulating hormone and luteinizing hormone receptor messenger RNAs in the rat ovary. Molecular Endocrinology 5 1405-1417.

Chun SY, Billig H, Tilly JL, Furuta I, Tsafriri A \& Hsueh AJ 1994 Gonadotropin suppression of apoptosis in cultured preovulatory follicles: mediatory role of endogenous insulin-like growth factor I. Endocrinology 135 1845-1853.

Chun SY, Eisenhauer KM, Minami S, Billig H, Perlas E \& Hsueh AJ 1996 Hormonal regulation of apoptosis in early antral follicles: follicle-stimulating hormone as a major survival factor. Endocrinology 137 1447-1456.

Dorrington JH, Moon YS \& Armstrong DT 1975 Estradiol-17 $\beta$ biosynthesis in cultured granulosa cells from hypophysectomized immature rats: stimulation by follicle-stimulating hormone. Endocrinology 97 1328-1331.

Dunkel L, Tilly JL, Shikone T, Nishimori S \& Hsueh AJW 1994 Follicle-stimulating hormone receptor expression in the rat ovary: increases during prepubertal development and regulation by the opposing actions of transforming growth factors $\beta$ and $\alpha$. Biology of Reproduction $\mathbf{5 0}$ 940-948.

Erickson GF \& Hsueh AJW 1978 Stimulation of aromatase activity by follicle-stimulating hormone in rat granulosa cells in vivo and in vitro. Endocrinology 102 1275-1282.

Fitzpatrick SL \& Richards JS 1991 Regulation of cytochrome P450 aromatase messenger RNA and activity by steroids and gonadotropins in rat granulosa cells. Endocrinology 129 1452-1462.

Fortune JE 1994 Ovarian follicular growth and development in mammals. Biology of Reproduction 50 225-232.

Gitay-Goren H, Kim I-C, Miggans ST \& Schomberg DW 1993 Transforming growth factor beta modulates gonadotropin receptor expression in porcine and rat granulosa cells differently. Biology of Reproduction 48 1284-1289.

Goodman SB, Kugu K, Chen SH, Preutthipan S, Tilly KI, Tilly JL \& Dharmarajan AM 1998 Estradiol-mediated suppression of apoptosis in the rabbit corpus luteum is associated with a shift in expression of $b c l-2$ family members favoring cellular survival. Biology of Reproduction 59 820-827.

Hakuno N, Koji T, Yano T, Kobayashi N, Tsutsumi O, Taketani Y \& Nakane PK 1996 Fas/APO-1/CD95 system as a mediator of granulosa cell apoptosis in ovarian follicle atresia. Endocrinology 137 1938-1948.

Hickey GJ, Chen S, Besman MJ, Shively JE, Hall PF, Gaddy-Kurten D \& Richards JS 1988 Hormonal regulation, tissue distribution and content of aromatase cytochrome P450 messenger ribonucleic acid and enzyme in rat ovarian follicles and corpora lutea: relationship to estradiol biosynthesis. Endocrinology 122 1426-1436.

Hickey GJ, Krasnow JS, Beattie WG \& Richards JS 1990 Aromatase cytochrome P450 in rat ovarian granulosa cells before and after luteinization: adenosine 3', 5'-monophosphate-dependent and independent regulation, cloning and sequencing of rat aromatase cDNA and 5' genomic DNA. Molecular Endocrinology 4 3-12.

Hooley RD, Findlay JK \& Stephenson RG 1979 Effect of heat stress on plasma concentrations of prolactin and luteinizing hormone in ewes. Australian Journal of Biological Sciences 32 231-235.

Hsueh AJ \& Erickson GF 1978 Glucocorticoid inhibition of $\mathrm{FSH}$-induced estrogen production in cultured rat granulosa cells. Steroids 32 639-648.

Hsueh AJW, Billig H \& Tsafriri A 1994 Ovarian follicle atresia: a hormonally controlled apoptotic process. Endocrine Reviews 15 $707-724$.

Kanai Y \& Shimizu H 1986 Changes in plasma concentration of luteinizing hormone, progesterone and oestradiol-17 $\beta$ during the periovulatory period in cyclic swamp buffaloes (Bubalus bubalis). Animal Reproduction Science 11 17-24. 
Kawate N, Inaba T \& Mori J 1990 A quantitative comparison in the bovine of steroids and gonadotropin receptors in normally developing follicles and in follicular and luteinized cysts. Animal Reproduction Science 23 273-281.

Kim JM, Boone DL, Auyeung A \& Tsang BK 1998 Granulosa cell apoptosis induced at penultimate stage of follicular development is associated with increased levels of Fas and Fas ligand in the rat ovary. Biology of Reproduction 58 1170-1176.

Krasnow JS, Hickey GJ \& Richards JS 1990 Regulation of aromatase mRNA and estradiol biosynthesis in rat ovarian granulosa and luteal cells by prolactin. Molecular Endocrinology 4 13-21.

LaPolt PS, Tilly JL, Aihara T, Nishimori K \& Hsueh AJ 1992 Gonadotropin-induced up- and down-regulation of ovarian follicle-stimulating hormone (FSH) receptor gene expression in immature rats: effects of pregnant mare's serum gonadotropin, human chorionic gonadotropin, and recombinant FSH. Endocrinology 130 1289-1295.

Nakamura K, Minegishi T, Takakura Y, Miyamoto K, Hasegawa Y, Ibuki Y \& Igarashi M 1991 Hormonal regulation of gonadotropin receptor mRNA in rat ovary during follicular growth and luteinization. Molecular and Cellular Endocrinology 82 259-263.

Oltvai ZN, Milliman CL \& Korsmeyer SJ 1993 Bcl-2 heterodimerizes in vivo with a conserved homolog, Bax, that accelerates programmed cell death. Cell 74 609-619.

Palumbo A \& Yeh J 1994 In situ localization of apoptosis in the rat ovary during follicular atresia. Biology of Reproduction $\mathbf{5 1}$ 888-895.

Peng X-R, Hsueh AJW, LaPolt PS, Bjersing L \& Ny T 1991 Localization of luteinizing hormone receptor messenger ribonucleic acid expression in ovarian cell types during follicle development and ovulation. Endocrinology 129 3200-3207.

Quirk SM, Cowan RG, Joshi SG \& Henrikson KP 1995 Fas antigenmediated apoptosis in human granulosa/luteal cell. Biology of Reproduction 52 279-289.

Roy SK \& Greenwald GS 1985 An enzymatic method for dissociation of intact follicles from the hamster ovary: histological and quantitative aspect. Biology of Reproduction 32 203-215.

Shimizu T, Ohshima I \& Kanai Y 2000 Effect of heat stress on follicular development in PMSG-treated immature rats. Animal Science Journal 71 32-37.

Teerds KJ \& Dorrington JH 1995 Immunolocalization of transforming growth factor $\alpha$ and luteinizing hormone receptor in healthy and atretic follicles of the adult rat ovary. Biology of Reproduction $\mathbf{5 2}$ 500-508

Thatcher WW, Driancourt DD, Terqui M \& Badinga L 1991 Dynamics of ovarian follicular development in cattle following hysterectomy and during early pregnancy. Domestic Animal Endocrinology 8 223-234.
Tilly JL 1993 Ovarian follicular atresia: a model to study the mechanisms of physiological cell death. Endocrine Journal 1 67-72.

Tilly JL 1996 Apoptosis and ovarian function. Reviews of Reproduction 1 162-172.

Tilly JL, Billig H, Kowalski KI \& Hsueh AJ 1992a Epidermal growth factor and basic fibroblast growth factor suppress the spontaneous onset of apoptosis in cultured rat ovarian granulosa cells and follicles by a tyrosine kinase-dependent mechanism. Molecular Endocrinology 6 1942-1950.

Tilly JL, LaPolt PS \& Hsueh AJW 1992b Hormonal regulation of follicle-stimulating hormone receptor messenger ribonucleic acid levels in cultured rat granulosa cells. Endocrinology $\mathbf{1 3 0}$ 1296-1302.

Tilly JL, Tilly KI, Kenton ML \& Johnson AL 1995 Expression of members of the $b c l-2$ gene family in the immature rat ovary: equine chorionic gonadotropin-mediated inhibition of granulosa cell apoptosis is associated with decreased bax and constitutive bcl-2 and $\mathrm{bcl}$-xlong messenger ribonucleic acid levels. Endocrinology $136232-241$.

Tsai-Morris CH, Ghosh M, Hirshfield AN, Wise PM \& Brodie AMH 1983 Inhibition of ovarian aromatase by prolactin in vivo. Biology of Reproduction 29 342-346.

Weiner KX \& Dias JA 1993 Regulation of ovarian ornithin decarboxylase activity and its mRNA by gonadotropins in the immature rat. Molecular and Cellular Endocrinology 92 195-199.

Wilson SJ, Marion RS, Spain JN, Spiers DE, Keisler DH \& Lucy MC 1998a Effects of controlled heat stress on ovarian function of dairy cattle. I. Lactating cows. Journal of Dairy Science $\mathbf{8 1}$ $2124-2131$.

Wilson SJ, Kirby CJ, Koenigsfeld AT, Keisler DH \& Lucy MC $1998 b$ Effects of controlled heat stress on ovarian function of dairy cattle. II. Heifers. Journal of Dairy Science $812132-2138$.

Wolfenson D, Lew BJ, Thatcher WW, Graber Y \& Meidan R 1997 Seasonal and acute heat stress effects on steroid production by dominant follicles in cows. Animal Reproduction Science 47 9-19.

Yang E, Zha J, Jockel J, Boise LH, Thompson CB \& Korsmeyer SJ $1995 \mathrm{Bad}$, a heterodimeric partner for $\mathrm{Bcl}-\mathrm{XL}$ and $\mathrm{Bcl}-2$, displaces Bax and promotes cell death. Cell $80285-291$.

Zhou J, Kumar RT, Matzuk MM \& Bondy C 1997 Insulin-like growth factor I regulates gonadotropin responsiveness in the murine ovary. Molecular Endocrinology 11 1924-1933.

Received 30 September 2004

First decision 18 November 2004

Accepted 21 December 2004 